\author{
Loyalitas Kreativitas \\ Aldi Masyarakat Kreatif
}

P-ISSN 2722-2101, E-ISSN 2722-4201

Program Studi Ekonomi Manajemen Universitas Pamulang

Jurnal LOKABMAS Kreatif Vol.02,No.01,Maret 2021 Hal. 64-70

Email:jurnalkreatif.manajemen@gmail.com

\title{
PENGABDIAN KEPADA MASYARAKAT PEMBINAAN STRATEGIS PENGELOLAAN KEUANGAN KELUARGA DI MASA PANDEMI DAN PASCA PANDEMI COVID-19
}

\author{
Aod Abdul Jawad, Agus Mulyono, Yusup Purwanto \\ Dosen Teknik Industri Fakultas Teknik Universitas Pamulang \\ Email : \\ dosen02273@unpam.ac.id, dosen02255@unpam.ac.id, dosen02211@unpam.ac.id
}

\begin{abstract}
ABSTRAK
Kegiatan Pengabdian Kepada Masyarakat ini bertujuan dalam rangka memenuhi kewajiban dalam pelaksanaan Tri Darma Perguruan Tinggi dan untuk memberikan pengetahuan kepada masyarakat melalui pelatihan bagaimana cara mengelola keuangan keluarga di wilayah perumahan Mulya Asri 2 Desa Sukamulya Kecamatan Cikupa Kabupaten Tangerang yang terkena dampak ekonomi secara langsung akibat wabah Covid-19.

Hasil kegiatan PKM menunjukan bahwa permasalahan mitra, dengan adanya pandemic covid 19 yang mengakibatkan mereka tidak mendapatkan penghasilan seperti pedagang kecil, informal, ojol dan supir. Kami berinisiatif membantu program pemerintah dalam meringankan beban masyarakat khususnya masyarakat menengah kebawah yang sangat terpengaruh dengan adanya wabah covid 19 ini, dengan memberikan bantuan sembako sebagai bentuk langsung yang bias dikonsumsi untuk meringankan beban saudara kita yang terkena dampak virus corona. Selain penyampaian materi melalui pelatihan atau seminar, tim PKM juga menwarkan beberapa alternatif solusi usaha kecil untuk menambah pemasukan terutama bagi yang susah mencari rejeki pada saat wabah covid 19 ini menimpa kita semua.

Metode kegiatan yang digunakan adalah melakukan kerjasama dengan ibu-ibu anggota Majlis Ta'lim perumahan Mulya Asri 2 Sukamulya Cikupa Tangerang. Sebelum kegiatan dilaksanakan, kami melakukan komunikasi awal dengan pengurus lingkungan setempat yang kemudian dilakukan survei lapangan untuk mengetahui kondisi riil masayarakat dan mengidentifikasi keluarga sasaran dalam pelaksanaan kegiatan PKM. Setelah mendapatkan data keluarga yang memenuhi kriteria sebagai sasaran maka komunikasi lanjutan kepada pengurus lingkungan dalam menetukan waktu pelaksanaan dan teknis kegiatan. Harapannya kedepan pelatihan yang diberikan dapat membantu dan manfaatnya dapat berkelanjutan baik kepada keluarga yang mengikuti pelatihan maupun lingkungan sekitarnya.
\end{abstract}

\section{Kata kunci : Covid-19, pelatihan, keuangan, ekonomi}

\section{ABSTRAC}

This Community Service activity aims to fulfill obligations in implementing the Tri Darma of Higher Education and to provide knowledge to the community through training on how to manage family finances in the residential area of Mulya Asri 2, Sukamulya Village, Cikupa District, Tangerang Regency which is directly affected by the economic impact of the Covid-19 outbreak. 


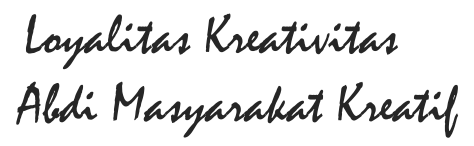

P-ISSN 2722-2101, E-ISSN 2722-4201

Program Studi Ekonomi Manajemen Universitas Pamulang Jurnal LOKABMAS Kreatif Vol.02,No.01,Maret 2021 Hal. 64-70

Email:jurnalkreatif.manajemen@gmail.com

The results of PKM activities show that the problems of partners, with the Covid 19 pandemic, have resulted in them not getting income such as small traders, informal, ojol and drivers. We took the initiative to help government programs in easing the burden on the community, especially the middle to lower class, who were very affected by the Covid 19 outbreak, by providing basic food assistance as a direct form that can be consumed to ease the burden on our relatives who are affected by the corona virus. In addition to delivering material through training or seminars, the PKM team also offered several alternative solutions for small businesses to increase income, especially for those who had difficulty finding fortune when the Covid 19 outbreak hit us all.

The activity method used is to collaborate with the members of the Majlis Ta'lim housing Mulya Asri 2 Sukamulya Cikupa Tangerang. Before the activity was carried out, we made initial communication with the local environmental committee, which then carried out a field survey to find out the real conditions of the community and identify target families in the implementation of PKM activities. After obtaining data on families that meet the criteria as targets, continued communication to the ward committee in determining the implementation time and technical activities. The hope is that in the future the training provided can help and the benefits will be sustainable for both the families who participated in the training and the surrounding environment.

Keywords: Covid-19, training, finance, economy

\section{PENDAHULUAN}

Sejak pandemi wabah covid-19 melanda dunia dan tidak terkecuali Indonesia sangat terlihat dampaknya terhadap penurunan derajat kemampuan keuangan para keluarga dan masyarakat secara luas. Gelombang PHK tidak dapat dihindarkan sebagai akibat produksi dan konsumsi di berjalan secara normal. Para pekerja ekonomi di sektor informal juga mengalami kebuntuan penghasilan karena akses dan aktifitasnya sangat terbatas terlebih pada masa PSBB (pembatasan sosial berskala besar) yang diterapkan pemerintah. Adanya penurunan dari sektor ekonomi, baik di perdagangan maupun perindustrian, pandemic covid-19 dan berlakunya PSBB, maka yang berjualan dan yang membeli berkurang. Yang akibatnya ekonomi masyarakat pun perputarannya saat ini sangat menurun karena banyak orang yang kehilangan pekerjaannya. Mengingat Indonesia masih terdapat banyak garis-garis kemiskinan diberbagai daerah dengan kondisi serba kekurangan dan keterbatasan ditengah wabah covid-19 membuat kesejahteraan masyarakat secara tidak langsung akan mengalami penurunan. Akibatnya, masih banyak masyarakat kecil dan kurang mampu mengalami berbagai hambatan seperti kebutuhan finansial yang kurang dalam membeli kebutuhan pokok dan sebagainya dapat dikatakan belum menjalani kehidupan secara layak.

Seperti yang kita ketahui bersama kesejahteraan masyarakat berkaitan erat dengan masalah kesehatan khususnya kalangan masyarakat kecil kebawah saat ini di uji akibat adanya wabah covid-19 seperti contohnya berupa vitamin dan obat-obatan yang dimana stok persediaan dirumah mereka saja tidak ada sama sekali bahkan masih belum mendapatkan perhatian dari pemerintah setempat. Dengan adanya wabah covid-19 yang bisa saja mereka terserang kapan saja apabila tidak ditangani secara cepat oleh pemerintah. Menjadi tanggungjawab dan tugas bersama untuk memberikan bantuan dan menunjukkan kepedulian sesama dalam meringankan beban yang dirasakan. Bantuan ekonomi langsung 


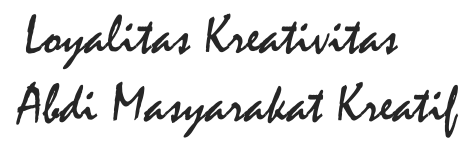

P-ISSN 2722-2101, E-ISSN 2722-4201

Program Studi Ekonomi Manajemen Universitas Pamulang

Jurnal LOKABMAS Kreatif Vol.02,No.01,Maret 2021 Hal. 64-70

Email:jurnalkreatif.manajemen@gmail.com berbentuk langsung berupa misalnya bahan pokok dan lainnya sangat membantu dan hal yang sangat dibutuhkan.

Kegiatan pemberdayaan ekonomi masyarakat adalah salah satu hal yang dibutuhkan pada mas krisis ekonomi seperti saat ini. Bentuk-bentuk kegiatan pemberdayaan tersebut adalah :

a. Membangkitkan harga diri kaum dhuafa, membangkitkan harga diri ini dapat dilakukan seperti mana yang dilakukan oleh

Rasulullah

Sollallohualaihiwassallam adalah dengan mendekatkan diri dan bergaul dengan mereka. Mereka perlu mendapatkan perhatian, penghargaan, pujian, kegembiraan, kemuliaan, doa, kasih sayang dan lainnya.

b. Memberikan motivasi, hal ini diperlukan untuk memacu semangat berusaha dan bekerja bagi kaum dhuafa.

c. Memberikan pelatihan yang bisa menopang kemandiriaan yang sesuai dengan kemampuan mereka

d. Memberikan jaminan dan bantuan sosial untuk meringankan beban keluarga terdampak.

Berdasarkan latar belakang tersebut, kami dari Tim Program Pengabdian Masyarakat (PKM) Universitas Pamulang (UNPAM) yang berjumlah 3 dosen terpanggil untuk ikut serta membantu memecahkan persoalan yang dihadapi oleh masyarakat Mulya Asri 2, Sukamulya Cikupa Tangerang dengan mengadakan bakti sosial dan pelatihan ketrampilan sederhana dalam meringankan beban ekonomi dan ketahan ekonomi keluarga dengan judul "Pembinaan Strategis Pengelolaan Keuangan Keluarga di Masa dan Pasca Pandemi Covid-19”

\section{RUMUSAN MASALAH}

Berdasarkan analisa situasi di atas maka dapat diperoleh rumusan masalah yang dihadapi masyarakat yang terdampak covid19 adalah :

1. Bagaimana solusi meringankan beban ekonomi bagi warga Mulya Asri Sukamulya Cikupa Tangerang dalam masa pandemic Covid-19?

2. Bagaimana solusi yang bersifat jangka menengah ataupun jangka panjang yang mampu membantu menumbuhkan ketahanan ekonomi keluarga dalam masa pandemic Covid19?

\section{TUJUAN PELAKSANAAN}

Berdasarkan rumusan masalah yang ada maka tujuan dari Pengabdian Kepada Masyarakat ini adalah :

1. Untuk memberikan bantuan secara langsung untuk meringankan beban ekonomi dalam wabah Covid-19.

2. Untuk memberikan pelatihan sederhana dalam membantu ketahanan ekonomi keluarga dalam wabah Covid-19.

\section{TINJAUAN PUSTAKA}

\section{Definisi Laporan Keuangan}

Laporan keuangan atau dalam bahasa inggris disebut financial statement merupakan hasil akhir dari suatu proses pencatatan kegiatan transaksi keuangan dalam sebuah suatu perusahaan yang menggambarkan keadaan keuangan perusahaan itu di satu periode akuntansi serta merupakan gambaran umum tentang kinerja suatu perusahaan. Adapun pendapat lain yang menyebutkan, bahwa laporan keuangan merupakan suatu produk akhir proses akuntansi dalam sebuah perusahaan pada satu periode tertentu di mana informasi di dalamnya adalah hasil pengumpulan sekaligus pengolahan data keuangan, dengan tujuan guna membantu perusahaan membuat keputusan atau kebijakan yang tepat. Dalam penyusunan laporan keuangan ini memakai berbagai sumber data dalam pembuatannya. Seperti faktur, bon, nota kredit, laporan, bank dan lain sebagainya. Dan 


\section{Loyalitas Kreativitas Aldi Masyarakat Kreatif}

P-ISSN 2722-2101, E-ISSN 2722-4201

Program Studi Ekonomi Manajemen Universitas Pamulang Jurnal LOKABMAS Kreatif Vol.02,No.01,Maret 2021 Hal. 64-70

Email:jurnalkreatif.manajemen@gmail.com dari sumber data tersebut nantinya akan dipakai untuk mengisi buku perkiraan serta sebagai bukti keabsahan transaksi.

\section{Tujuan Laporan Keuangan}

Pada umumnya, tujuan dari pembuatan laporan keuangan ini tak lain guna menunjukan mengenai informasi apa yang akan dihasilkan oleh akuntansi keuangan. Dalam tujuan itu, tak disebutkan secara detail ditujukan ke siapa informasi keuangan itu. Tetapi, secara implisit bisa disimpulkan bahwa yang dituju merupakan pihak investor dan kreditor.

\section{Fungsi Laporan Keuangan}

Pada umumnya, fungsi dari laporan keuangan ini adalah sebagai alat untuk membantu perusahaan dalam menilai keadaan keuangan perusahaan. Tapi tidak hanya sebatas untuk perusahaan saja, di saat pandemi ini ibuibu sebagai pelaksana harian dalam rumah tangga juga dapat merasakan manfaat dari laporan keuangan tersebut.

Adapun beberapa fungsi lainnya dari laporan keuangan ini, diataranya ialah sebagai berikut:

1. Sebagai Media Review

Financial statement bisa menyajikan informasi atau data yang komprehensif mengenai kedudukan keuangan perusahaan. Hal tersebut dapat menjadi ulasan tentang keadaan perusahaan secara menyeluruh, terutama keadaan keuangan (aset, utang, biaya operasional, dan yang lainnya).

\section{Sebagai Pedoman Membuat Keputusan}

Salah satu fungsi paling penting dalam pembuatan laporan tentang keadaan keuangan perusahaan yaitu sebagai media pertimbangan dalam pengambilan keputusan penting untuk perusahaan.

3. Membantu Menciptakan Strategi Baru

Financial statement juga bisa digunakan dalam membuat strategi baru oleh perusahaan dalam usaha menaikan performa usahanya.

Manfaat Laporan Keuangan menurut (Irham, 2012) :
"Dengan terdapatnya laporan keuangan yang disediakan oleh pihak manajemen perusahaan maka akan sangat membantu pihak pemegang saham dalam proses pengambilan keputusan, serta sangat bermafaat dalam melihat keadaan pada saat ini ataupun dijadikan sebagai alat untuk memprediksi keadaan masa yang akan datang".

\section{METODE PELAKSANAAN}

Hal mendasar yang ditawarkan untuk ikut memecahkan masalah adalah melalui kegiatan pembinaan dan pendampingan masyarakat Perumahan Mulya Asri 2 yang dikemas dengan nama kegiatan "Pembinaan Strategis Pengelolaan Keuangan Keluarga di Masa dan Pasca Pandemi Covid-19”.

Yang menjadi sasaran dalam kegiatan (PKM) Pengabdian Kepada Masyarakat ini adalah beberapa keluarga di lingkungan Perumahan Mulya Asri 2 Sukamulya Cikupa Tangerang yang mengalami kesulitan ekonomi sebagai akibat pandemi Covid 19.

Metode kegiatan yang digunakan dalam kegiatan ini yaitu memberikan pelatihan pengelolaan keuangan keluarga pada masa dan pasca pandemi covid-19. Program Pengabdian Kepada Masyarakat di Perumahan Mulya Asri 2 Desa Sukamulya Kecamatan Cikupa Kabupaten Tangerang ini bagi menjadi 3 tahapan, tahap pertama persiapan yaitu komunikasi pendahuluan dan survey lapangan, tahap kedua pelaksanaan, yaitu pemberian bantuan dan pelatihan, tahap ketiga evaluasi. Berikut adalah bagan alur dari setiap rangkaian kegiatan.

1) Tahap Persiapan, adapun tahap-tahap yang kami lakukan dalam Pengabdian Kepada Masyarakat meliputi :

Komunikasi dan survei pendahuluan, pada tahap ini kami membangun komunikasi awal dengan pengurus lingkungan dan melakukan survey lapangan kepada keluarga sasaran 
Loyalitas Kreativitas
Aldi Masyarakat Kreatif
P-ISSN 2722-2101, E-ISSN 2722-4201

Program Studi Ekonomi Manajemen Universitas Pamulang

Jurnal LOKABMAS Kreatif Vol.02,No.01,Maret 2021 Hal. 64-70

Email:jurnalkreatif.manajemen@gmail.com
- $\quad$ sesuai informasi pengurus lingkungan. Setelah kami mendapatkan data keluarga yang sesuai sasaran PKM.

- $\quad$ Pemantapan dan penentuan lokasi dan sasaran. Setelah survey dilakukan maka ditentukan lokasi pelaksanaan dan sasaran yang benar-benar membutuhkan bantuan.

2) Tahap Pelaksanaan, permasalahan yang ada adalah penurunan penghasilan yang drastis akibat pandemi Covid-19 seperti pedagang kecil, informal, ojol dan supir. Setelah itu kita para dosen menggalang dana untuk pembelian sembako yang akan dibagikan. Lalu setelah dana terkumpul kita membelanjakan dana tersebut dengan sembako yang kemudian di distribusikan ke kelurga sesuai sasaran yang telah ditetapkan. Waktu pelaksanaan program pengabdian kepada masyarakat ini berjalan dari tanggal $21-22$ November 2020. Kegiatan pengabdian ini dikemas dalam bentuk pemberian materi mengelola keuangan. Pelatihan tersebut dirancang agar warga binaan tersebut memiliki keterampilan tambahan dan dapat mengkonsumsi untuk kebutuhan sehari-hari bahkan untuk pengembangan skala yang lebih besar bila memungkinkan.

3) Tahap Evaluasi, pada tahap evaluasi ini untuk mengetahui seberapa berhasilkah pengelolaan keuangan di masa pandemi yang telah diberikan, yakni melalui apakah kegiatan berjalan lancar sehingga masyarakat penerima dapat merasakan manfaatnya dengan sebaik mungkin. Evaluasi ini penting sebagai tahap monitoring apakah PKM yang telah kita lakukan sudah berhasil atau belum.

\section{HASIL DAN PEMBAHASAN}

Pelatihan pengelolaan keuangan telah memberikan ketrampilan baru dan sebuah asa dalam menatap dan menghadapi tantangan kehidupan khususnya pada masa ekonomi sulit sebagai akibat pandemic covid 19. Pemberian pelatihan pengelolaan keuangan ini juga dapat membangun kemandirian ekonomi berkelanjutan bila secara ekonomi bernilai dalam skala yang lebih besar.

Untuk lebih jelasnya, tahapan kegiatan PKM ini dapat dijelaskan melalui gambar berikut ini :

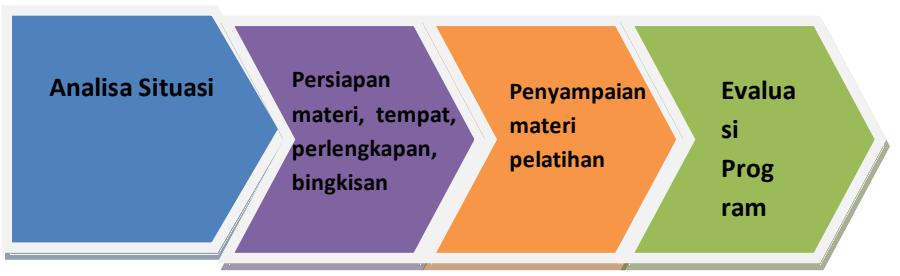

Luaran yang diharapkan dalam program ini adalah membantu program pemerintah dalam meringankan beban masyarakat khususnya masyarakat menengah kebawah yang sangat terpengaruh dengan adanya wabah covid19 ini, dengan memberikan memberikan pelatihan pengelolaan keuangan yang dapat membangun kemandirian ekonomi berkelanjutan bila secara ekonomi bernilai dalam skala yang lebih besar.

Ada beberapa strategi pemberdayaan masyarakat yang bisa menjadi pilihan dalam melaksanakan pemberdayaan masyarakat antara lain : 


\section{Loyalitas Kreativitas \\ Aldi Masyarakat Kreatif}

P-ISSN 2722-2101, E-ISSN 2722-4201

Program Studi Ekonomi Manajemen Universitas Pamulang

Jurnal LOKABMAS Kreatif Vol.02,No.01,Maret 2021 Hal. 64-70

Email:jurnalkreatif.manajemen@gmail.com
1. Strategi dengan tiga pendekatan, yaitu :

$>\quad$ Pendekatan Mikro, pemberdayaan dilakukan terhadap klien secara individu melalui bimbingan, konselling, stress management, crisiss intervention. Tujuan utamanya untuk membimbing atau melatih klien dalam menjalankan tugas-tugas kehidupannya. Model ini sering disebut sebagai pendekatan yang berpusat pada tugas (task centered approach).

$>$ Pendekatan Mezzo, pemberdayaan dilakukan terhadap kelompok klien. Pemberdayaan dilakukan dengan menggunakan kelompok sebagai media intervensi. Pendidikan dan pelatihan, dinamika kelompok, biasanya digunakan sebagai strategi dalam meningkatkan kesadaran, pengetahuan, keterampilan dan sikap-sikap klien agar mampu memiliki kemampuan memecahkan permasalahan yang dihadapi.

Pendekatan Makro, pendekatan ini disebut juga sebagai strategi besar, karena sasaran perubahan di arahkan pada system lingkungan yang lebih luas. Perumusan kebijakan, perencanaan sosial, kampanye, aksi sosial, lobbying, pengorganisasian masyarakat, manajemen konflik, adalah beberapa strategi dalam pendekatan ini. Strategi sistem besar memandang klien sebagai orang yang memiliki kompetensi untuk memahami situasi-situasi mereka sendiri dan untuk memilih serta menentukan strategi yang tepat untuk bertindak.

2. Strategi dengan 5P, menurut Suharto dalam Oos M. Anwas 30 yaitu : pemungkinan, penguatan, perlindungan, penyokongan dan pemeliharaan.

\section{KESIMPULAN DAN SARAN}

\section{Kesimpulan}

Pelaksanaan kegiatan pengabdian kepada masyarakat dengan memberikan seminar dan pelatihan mengenai pengelolaan keuangan kepada warga masyarakat di lingkungan perumahan Mulya Asri 2 Sukamulya Cikupa Tangerang, kami mengucapkan rasa syukur Alhamdulillah kepada Allah SWT, sehingga kegiatan ini berjalan sesuai dengan yang kita harapkan. Begitu juga terima kasih kepada seluruh pihak yang turut serta dalam pelaksanaan kegiatan ini.

\section{Saran}

1) Diharapkan untuk dapat mempersiapkan ini dengan matang sehingga penggalian dana lebih besar sehingga skala jumlah keluarga yang diberikan bantuan dan pelatihan bisa lebih luas.

2) Menciptakan dan menjalin komunikasi yang lebih intens dengan pengurus lingkungan daerah sasaran sehingga hasil optimal.

\section{DAFTAR PUSTAKA}

Pasal 4 ayat (1) Undang- Undang Dasar Negara Repubik Indonesia Tahun 1945

UU No.6 Tahun 2018 tentang Karantina Kesehatan (Lembaga Negara Republik Indonesia Tahun 2018 Nomor 128, Tambahan Lembaran Negara Republik Indonesia Nomor 6236);

Peraturan Pemerintah Republik Indonesia Nomor 21 Tahun 2020 Tentang Pembatasan Sosial Berskala Besar Dalam Rangka 
Loyalitas Kreativitas
Aldi Masyarakat Kreatif
P-ISSN 2722-2101, E-ISSN 2722-4201

Program Studi Ekonomi Manajemen Universitas Pamulang

Jurnal LOKABMAS Kreatif Vol.02,No.01,Maret 2021 Hal. 64-70

Email:jurnalkreatif.manajemen@gmail.com

Percepatan

Penanganan Corona Virus Disease 2019 (covid19)

Keputusan Presiden Republik Indonesia Nomor 11 tahun 2020 Tentang penetapan kedaruratan kesehatan masyarakat corona virus disease 2019 (covid-19)

Peraturan Gubernur Nomor 27 tahun 2020 tentang Pedoman PSBB

Jurnal.id (2019, Maret 12). Retrieved

from:https://jurnal.id:https://www.jurnal.id/id/bl og/strategi-bisnis-untuk-bersaing

https://tirto.id/pertumbuhan-ekonomi minuscatatan-buruk-krisis-ekonomi-ri-9798-eKbR

\section{DOKUMENTASI FOTO KEGIATAN}
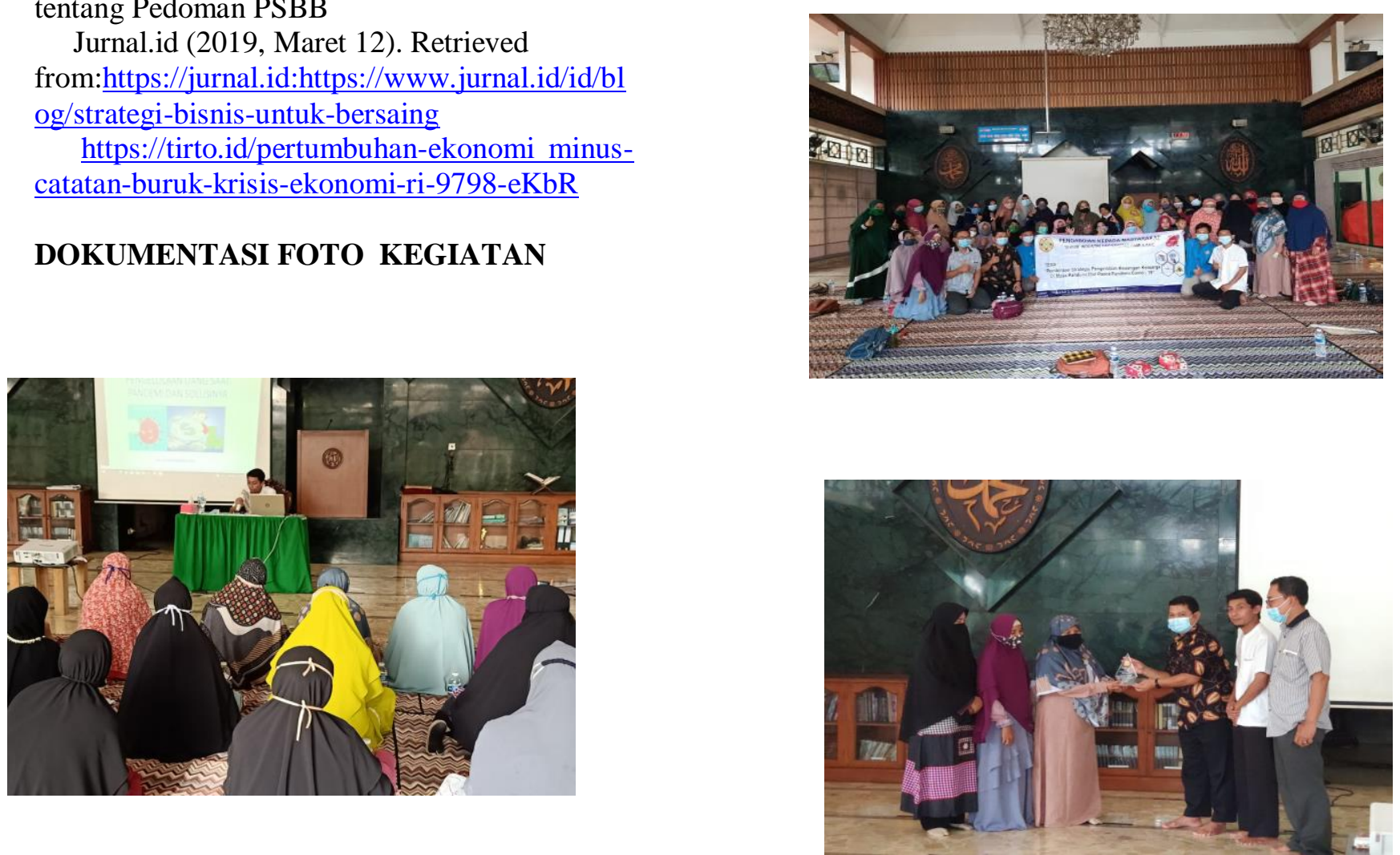